UDK $577.1: 61$

ISSN 1452-8258

J Med Biochem 39: 7-12, 2020

\title{
CAN NEUTROPHIL/LYMPHOCYTE RATIO BE USED AS AN INDICATOR OF INFLAMMATION IN PATIENTS WITH HYPERTHYROIDISM?
}

\section{DA LI SE ODNOS NEUTROFILA/LIMFOCITA MOŽE KORISTITI KAO INDIKATOR UPALE KOD PACIJENATA SA HIPERTIREOIDIZMOM?}

\author{
Murat Dağdeviren ${ }^{1}$, Tolga Akkan¹, Dilek Yapar², Serdar Karakaya², Tanyel Dağdeviren³, \\ Derun Ertuğrul ${ }^{1}$, Mustafa Altay ${ }^{1}$ \\ ${ }^{1}$ University of Health Science, Keçiören Health Administration and Research Center, \\ Department of Endocrinology and Metabolism, Ankara, Turkey \\ ${ }^{2}$ University of Health Science, Keçiören Health Administration and Research Center, \\ Department of Internal Medicine, Ankara, Turkey \\ ${ }^{3}$ University of Health Science, Keçiören Health Administration and Research Center, \\ Department of Family Practice, Ankara, Turkey
}

\section{Summary}

Background: In our study, we aimed to evaluate changes in the neutrophil and lymphocyte series and investigate whether the neutrophil/lymphocyte ratio (NLR) is indicative of inflammations in patients with hyperthyroidism.

Methods: A total of 161 patients were enrolled, 121 of which had hyperthyroidism (71 Graves' Disease (GD) and 50 non-Graves hyperthyroidism (NGH) patients) and 40 of which were control group members. Retrospectively, patients' neutrophil and lymphocyte counts were taken, and the NLR was calculated.

Results: While the number of neutrophils was significantly lower in the GD group ( $p=0.003)$, there was no significant difference between the NGH and the control group. In the GD group, NLR values were significantly lower than the other two groups (median 1.39 for GD, median 1.84 for $\mathrm{NGH}$ and median 1.83 for the control group, $\mathrm{p}<0.001$ ). Only three patients in the GD group had neutropenia. There was also a significant negative correlation between free T3 and neutrophil count and NLR in hyperthyroid patients $(r=$ $-0.28, p=0.001$ and $r=-0.34, p<0.001$, respectively). Conclusions: In our study, we found that NLR did not increase in hyperthyroid patients and that this ratio decreased due to the decrease in neutrophil levels in GD. We thus concluded that NLR is not a suitable indicator of hyperthyroidism.

Keywords: hyperthyroidism, lymphocyte, neutrophil, ratio

Address for correspondence:

Dr. Murat Dağdeviren

Keçiören Training and Research Hospital, Department of

Endocrinology and Metabolism, Pınarba I neighborhood,

25 Ardahan street, zip code: 06280, Keçiören, Ankara, Turkey

Telephone: +903123569000

\section{Kratak sadržaj}

Uvod: Cilj naše studije je bio da procenimo promene u seriji neutrofila i limfocita i istražimo da li je odnos neutrofila/limfocita (NLR) indikativan za upale kod pacijenata sa hipertireoidizmom.

Metode: Ukupno je bio uključen 161 bolesnik, od kojih je 121 imao hipertireoidizam (71 sa Grejvsovom bolešću (GD) i 50 njih sa hipertireoidizmom koji nije u vezi sa Grejvsovom bolešću (NGH)), dok su 40 njih bili članovi kontrolne grupe. Retrospektivno su uzeti broj neutrofila i limfocita pacijenata i izračunat je NLR.

Rezultati: Dok je broj neutrofila bio značajno niži u GD grupi ( $p=0,003$ ), nije bilo značajne razlike između $\mathrm{NGH}$ i kontrolne grupe. U GD grupi su vrednosti NLR bile značajno niže od ostalih dveju grupa (medijan 1,39 za GD, medijan 1,84 za NGH i medijan 1,83 za kontrolnu grupu, $p<0,001)$. Samo tri pacijenta u GD grupi su imala neutropeniju. Takođe, postojala je značajna negativna korelacija između slobodnog T3 i broja neutrofila i NLR kod hipertireoidnih pacijenata $(r=-0,28, p=0,001$ i $r=-0,34, p<$ 0,001, redom).

Zaključak: U našoj studiji smo otkrili da se NLR nije povećao kod hipertireoidnih pacijenata i da se taj odnos smanjio zbog smanjenja nivoa neutrofila u GD. Tako smo zaključili da NLR nije pogodan pokazatelj hipertireoidizma.

Ključne reči: hipertiroidizam, limfocit, neutrofil, odnos 


\section{Introduction}

Thyrotoxicosis refers to a clinical condition resulting from inappropriate high thyroid hormone effects in tissues. Hyperthyroidism is a type of thyrotoxicosis due to increased hormone synthesis and secretion in the thyroid gland. The two most common causes of hyperthyroidism are Graves' disease (GD) and toxic nodular goitre (1). The prevalence of hyperthyroidism is $0.8 \%$ in Europe and $1.3 \%$ in the USA (2, 3).

Hyperthyroidism is a form of inflammation caused by the systemic effects of increased thyroid hormones (4). This inflammation is much more evident in autoimmunity-related GD. Since antibodies against thyroid stimulating hormone (TSH) receptors primarily affect the thyroid, they also affect many cells such as adipocytes, fibroblasts, and bone cells $(5,6)$.

Neutrophil/lymphocyte ratio (NLR) has gained increasing importance in recent years and is an easily identifiable marker of inflammation (7). There are studies that NLR may be a marker of inflammation for a host of diseases such as familial Mediterranean fever, ankylosing spondylitis, rheumatic valve diseases, ulcerative colitis, psoriasis, coronary artery disease, malignancies, diabetes mellitus, hypertension, and chronic autoimmune thyroiditis $(8-11)$. There are also opinions that NLR can be used for predicting progression and mortality, and that it can be used as a disease activity indicator for certain diseases (12). Considering these findings, it is conceivable that NLR may be an indicator of inflammation in patients with hyperthyroidism, which is an inflammatory disease. Although it is known that hyperthyroidism may cause changes in a number of hematological parameters, the relationship between hyperthyroidism with NLR and inflammation is not yet known (13). Therefore, we have aimed to evaluate the changes in the neutrophil and lymphocyte series in hyperthyroid patients, as well as to investigate whether NLR could be an indicator of inflammation in this study.

\section{Materials and Methods}

First of all, approval was asked for from the local ethical commission before beginning the study. The work was conducted according to the principles of the Helsinki Declaration, and a written consent concerning the study was obtained from each of the participants.

The study included 150 hyperthyroid patients who had applied to the Endocrinology Outpatient Clinic between January 1, 2014, and January 1, 2016, as well as 40 healthy volunteers who had also applied to the same outpatient clinics within the same date range. Twenty-nine patients with active infection or malignancy, alongside those who had previously received anti-thyroid drugs for any reason, were not included in the study. 71 of 121 hyperthyroid patients had GD. Participants were assessed according to three groups: GD, non-GD hyperthyroidism (NGH) and control group. Data on age, gender, TSH, free $\mathrm{T3}$, free $\mathrm{T4}$, anti-thyroglobulin antibody (anti-Tg), anti-thyroid peroxidase antibody (anti-TPO), thyroid receptor antibody (TRAb), and whole blood counts were retrospectively obtained. Neutrophil and lymphocyte counts were determined, whereupon NLR values were calculated for each group.

Statistical analysis of the data was done using SPSS 22.0 software. For statistical significance, $\mathrm{p}<$ 0.05 was considered significant.

Descriptive statistics of patients and control groups were performed. Categorical values were reported in terms of number and percentage. Kolmogorov-Smirnov test and histogram graphs of the data were used to assess whether or not the data corresponded to normal distribution. Normal distributed data were expressed in terms of mean and standard deviation. Data that did not correspond to normal distribution were expressed in terms of median and minimum-maximum values. The Student's t-test was used in order to assess countable data that met the normal distribution, and the Mann-Whitney $U$ test was used to assess any countable data that did not fit the normal distribution. The Chi-Square test was used to compare the categorical variables. Pearson and Spearman correlation tests were applied during the analysis of correlations.

\section{Results}

$69 \%$ of the GD group, $70 \%$ of the NGH group and $75 \%$ of the control group were female. There was no statistically significant difference between the groups regarding gender. There was no significant difference in age between the GD and NGH groups. The control group consisted of patients who were younger than those of the other two groups (median age of 45 for the GD, 45.5 for the NGH, and 33.5 for the control groups, $p<0.001)$. In the GD group, the number of neutrophils was significantly lower than the other two groups $(p=0.003)$. There was no significant difference in the number of neutrophils between the NGH and control groups. The NLR values in the GD group were significantly lower than the other two groups (median of 1.39 for the GD, 1.84 for the $\mathrm{NGH}$, and 1.83 for the control groups, $\mathrm{p}<$ $0.001)$. There was no significant difference between $\mathrm{NGH}$ and control group in terms of NLR. Neutropenia was found in 3 patients in the GD group. However there was no neutropenia in the other two groups.

When the thyroid hormone and antibody parameters were examined, free T3 (fT3) values were significantly higher in the GD group than in the $\mathrm{NGH}$ group (9.11 versus $13.75 ; p=0.001)$. There was no 
Table I Demographic characteristics of groups, full blood count and NLR values.

\begin{tabular}{|c|c|c|c|c|}
\hline & $\begin{array}{l}\text { GD } \\
\mathrm{n}=71\end{array}$ & $\begin{array}{l}\mathrm{NGH} \\
\mathrm{n}=50\end{array}$ & $\begin{array}{c}\text { Control } \\
n=40\end{array}$ & $\mathrm{p}$ \\
\hline Female (\%) & 49 (69\%) & $35(70 \%)$ & $30(75 \%)$ & - \\
\hline Age (years) & 45 (19-69) & $45.5(20-83)$ & $33.5(21-67)$ & $<0.001$ \\
\hline $\begin{array}{l}\text { Leukocyte count } \\
\text { (cells } / \mu \mathrm{L})\end{array}$ & $6700(3200-12300)$ & 7400 (3900-13000) & 7200 (4800-13000) & - \\
\hline $\begin{array}{l}\text { Neutrophil count } \\
\text { (cells } / \mu \mathrm{L})\end{array}$ & $3400(1000-7500)$ & 4000 (1800-9300) & $4300(2100-8100)$ & 0.003 \\
\hline $\begin{array}{l}\text { Lymphocyte count } \\
\text { (cells/ } \mu \mathrm{L})\end{array}$ & $2400(600-5300)$ & 2250 (1100-4900) & $2200(1200-3600)$ & - \\
\hline NLR & $1.39(0.41-5.33)$ & $1.84(0.97-4.92)$ & $1.83(1-4.26)$ & $<0.001$ \\
\hline fT3 (pg/mL) & $13.75(3.01-30)$ & $9.11(4.47-30)$ & - & 0.001 \\
\hline fT4 (ng/mL) & $3.86(1.01-10)$ & $3.36(1.14-9.20)$ & $0.97(0.68-1.49)$ & $<0.001$ \\
\hline $\mathrm{TSH}(\mu \mathrm{U} / \mathrm{mL})$ & $0.004(0.001-0.068)$ & $0.005(0.004-0.21)$ & $2.08(0.53-4.45)$ & $<0.001$ \\
\hline $\operatorname{TRAb}(\mathrm{U} / \mathrm{L})$ & $4.81(0.72-405)$ & $3.47(1.07-59)$ & - & 0,03 \\
\hline Anti-TPO (U/mL) & $154.65(2.65-2000)$ & $9.5(0.7-1521)$ & - & $<0.001$ \\
\hline Anti-Tg (U/mL) & $46.07(5-5000)$ & $12.1(5-1329)$ & - & 0.03 \\
\hline
\end{tabular}

Contractions; GD: Graves' Disease, NGH: Non Graves' Disease Hyperthyroidism, NLR: Neutrophil Lymphocyte Ratio, fT3: free T3, fT4: free T4, TSH: Thyroid Stimulating Hormone, TRAb: Thyroid Receptor Antibody, Anti-TPO: Anti-thyroid peroxidase antibody, Anti-Tg: anti-thyroglobulin antibody

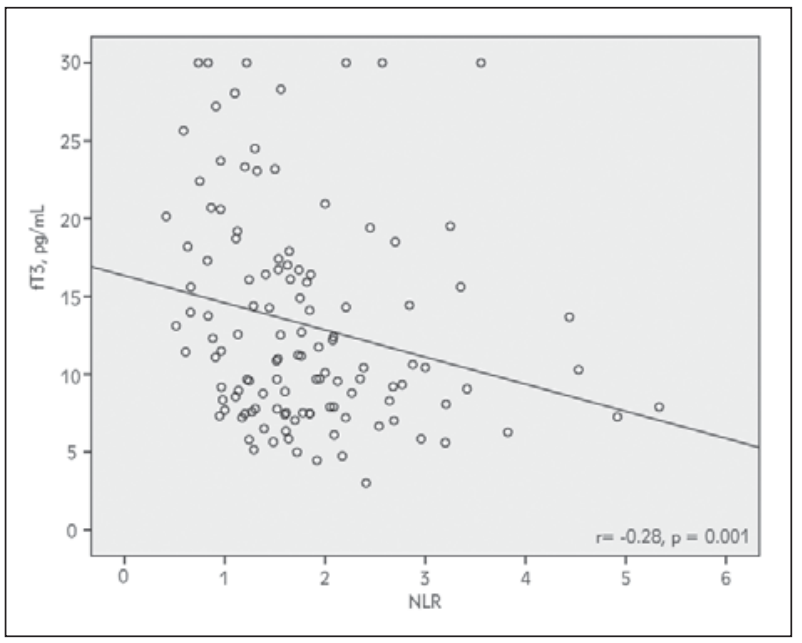

Figure 1 Correlation between fT3 and NLR.

significant difference in free T4 (fT4) and TSH values between the two groups. TRAb, anti-TPO, and anti-Tg were significantly higher in the GD group ( $p=0.03$, $\mathrm{p}<0.001$ and $\mathrm{p}=0.03$, respectively). When the control, GD, and $\mathrm{NGH}$ groups were compared in terms of fT4 and TSH, it was found that the TSH values were significantly higher and the fT4 values were significantly lower in the control group ( $p<0.001$ and $p<0.001$, respectively). The relevant data are provided in Table $I$.

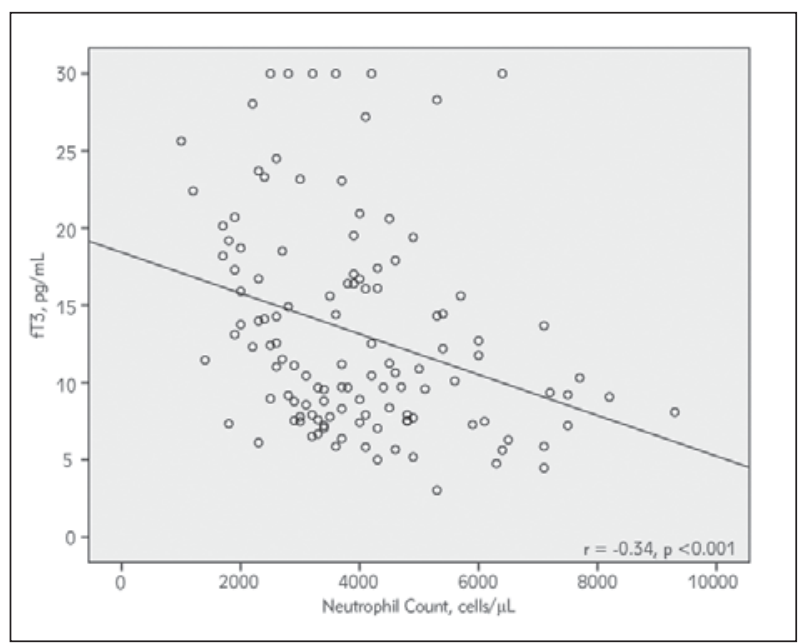

Figure 2 Correlation between fT3 and neutrophil count.

Significant differences were found only in fT3 levels between TRAb positive patients and TRAb negative patients (13.7 vs 9.8, $p=0.03$ ). However, no significant difference was found in terms of other parameters.

When the hyperthyroid patients (GD and NGH) were evaluated together, there was a significant negative correlation between the fT3 and NLR, as well as between fT3 and neutrophil counts $(r=-0.28, p=$ 
0.001 and $r=-0.34, p<0.001$, respectively) (Figures 1 and 2). Beyond this, no other significant correlation was found.

\section{Discussion}

In our study, we found that the NLR did not increase in hyperthyroid patients and that this ratio decreased due to the reduction in neutrophil levels in Graves' patients.

Neutropenia is generally defined as having an absolute neutrophil count below 1500 cells/microL. However, there are opinions based on different figures (14). The effects of anti-thyroid drugs on the granulocytic series (agranulocytosis and neutropenia) are well known; however, the data on the direct effect of thyroid diseases on granulocytes are limited. In addition, data on lymphocyte subpopulation distributions in thyroid patients with or without neutropenia are also inadequate $(15,16)$. Indeed, the relationship between thyroidopathy and neutropenia dates back over 100 years (16). Subsequently, studies have been carried out in hyperthyroid patients with hematological disorders (such as leukopenia) $(13,17)$. In various studies, the prevalence of neutropenia in hyperthyroid patients was found to be between $14.1 \%$ and $30 \%$ (18-20). Recently, Aggerwal et al. (18) found that 29 of the 209 Graves' patients were found to have neutropenia at the time of diagnosis. In this study and several previous small scale studies, neutropenia was also shown to improve after patients become euthyroid with treatment $(17,19,21)$. The rate of neutropenia in our study is rather low compared to previous studies. 71 of 3 Graves' patients (4.2\%) had neutropenia (neutrophil < 1500). Ethnic differences within the patient populations as well as differences in the hyperthyroid levels of the patients (especially fT3 levels) in the studies may have caused this. The difference in neutropenic reference values (e.g. $<1800$ and <2000) may have led to this situation. In our study, the patients' post-treatment status could not be assessed.

Three possible mechanisms in the thyroid-associated neutropenia are thought to play a role. These are humoral and cellular mechanisms as well as toxicity associated with direct thyroid hormone (16). Panossi et al. (22) have shown that a reduction in abnormal granulopoiesis and bone marrow granulocyte reserve in GD plays a role in the mechanism of neutropenia development. Shaw and Mehta (23) have also suspected that thyroid hormones might have an effect that directly inhibits the maturation and differentiation of pluripotent stem cells in the early stages of hematopoiesis. Moreover, experimental data has shown that normally high or low thyroid hormone exposure induces apoptosis of $\mathrm{CD}_{34}{ }^{+}$progenitor cells (24). Furthermore, pernicious anemia, which may accompany autoimmune thyroid diseases, is thought to contribute to the development of neutropenia (16).

In our study, we found a negative correlation between fT3 and neutrophil levels in GD patients. This was a finding supporting the direct toxic effect of thyroid hormone levels on neutrophils. As a matter of fact, in a number of previous studies, a negative correlation between $\mathrm{fT} 3$ level and the number of neutrophils was found $(16,18)$. In our study, only the detection of neutropenia in autoimmune thyroid patients suggests that immune reactions besides the hormone level may also be indicative of an important role in the development of neutropenia. However, no significant relationship was found between TRAb level and neutrophil count. Nevertheless, in some previous studies, a relationship between autoimmune thyroid disease and anti-neutrophil antibody (anti-PMN) was detected $(16,25)$. In 1985, Weitzman et al. (25) found that $50-55 \%$ of GD patients had a positive anti-PMN level, however, only $2 \%$ of them had neutropenia. Anti-PMN antibodies were detected in $37.2 \%$ of thyroid patients in the study of Kyritsi et al. (16), whereby the majority of which were autoimmune in origin. Considering previous studies in the literature, it can be considered that certain antibodies in addition to thyroid-related antibodies play a role in the development of some immuno-mediated hematologic disorders in autoimmune thyroid diseases. In our study, PMN antibody levels were not measured.

There was no significant difference in lymphocyte levels between the groups in our study. There are some studies in the literature reporting changes in peripheral lymphocyte subgroups in thyroid diseases $(26,27)$. However, these studies have very insufficient and contradictory results.

There are reports that NLR can be used as a systemic inflammation marker in many diseases with inflammation. In the studies of Keskin et al. (11), NLR was found to be significantly higher in euthyroid Hashimoto patients, and moreover, this ratio also showed a positive correlation with the autoantibody level. In the study of Kocer et al. (28) NLR was significantly higher in patients with papillary thyroid cancer. However, there are studies with different results and that show that this ratio is not increased in papillary thyroid cancer (29). This data suggests that NLR may be used as an inflammatory marker in thyroid diseases as well as in other diseases. However, in our study, changes in the granulocyte series in Graves' patients alongside no significant difference in $\mathrm{NGH}$ compared to the control group showed that NLR was not a suitable parameter to be used in these patients.

There are some restrictive factors in our study. First of all, our study was retrospective. Other inflammation markers such as sedimentation rate and Creactive protein were not evaluated. Furthermore, the anti-PMN antibody level thought to play a role in the development of neutropenia was not examined at all. 
There was also a significant age difference between the hyperthyroid patients and the control group. However, there was no significant age difference between the GD and NGH groups. It is thought that age is not an important factor in the results.

In conclusion, we believe that it would be inappropriate to use NLR as an inflammation marker in patients with hyperthyroidism. Nevertheless, we feel

\section{References}

1. De Leo S, Lee SY, Braverman LE. Hyperthyroidism. Lancet 2016; 388: 906-18.

2. Gligorovic Barhanovic N, Antunovic T, Kavaric S, Djogo Aleksandar, Kalimanovska Spasojevic V. Age and Assay Related Changes of Laboratory Thyroid Function Tests in the Reference Female Population. J Med Biochem 2019; 38: 22-32.

3. Rostami S, Fathollapour A, Abdiabdi M, Naderi K. Alteration in prooxidant-antioxidant balance associated with selenium concentration in patients with congenital hypothyroidism. J Med Biochem 2018; 37: 355-63.

4. Mancini A, Disegni C, Raimondo S, Olivieri G, Silvestrini A, Meucci E, et al. Thyroid hormones, oxidative stress, and inflamation. Mediators inflamm 2016; 6757154.

5. Davies TF, Ando T, Lin RY, Tomer Y, Latif R. Thyrotropin receptor-associated diseases: from adenomata to Graves disease. J Clin Invest 2005; 115: 1972.

6. Latif R, Morshed SA, Zaidi M, Davies TF. The thyroidstimulating hormone receptor: impact of thyroid-stimulating hormone and thyroid-stimulating hormone receptor antibodies on multimerization, cleavage, and signaling. Endocrinol Metab Clin North Am 2009; 38: 319.

7. Günes F, Asık M, Altun B, Sen H, Binnetoğlu E, Temiz A, et al. Carotid intima-media thickness and neutrophils/lymphocyte ratio in patients with overt and subclinical hypothyroidism. J Clin Exp Invest 2013; 4: 463-67.

8. Ahsen A, Ulu MS, Yuksel S, Demir K, Uysal M, Erdogan $M$, et al. As a new inflammatory marker for familial Mediterranean fever: neutrophil-to-lymphocyte ratio. Inflammation 2013; 36: 1357-62.

9. Gökmen F, Akbal A, Reşorlu H, Gökmen E, Güven M, Aras $A B$, et al. Neutrophil-Lymphocyte Ratio Connected to Treatment Options and Inflammation Markers of Ankylosing Spondylitis. J Clin Lab Anal 2015; 29: 29498.

10. Oztürk D, Erturk M, Celık O, Ozyılmaz S, Akturk F, Cakmak HA, et al. The role of the neutrophil/lymphocyte ratio in patients with rheumatic mitral stenosis as an indicator of spontaneous echocardiographic contrast. Kardiol Pol 2015; 72: 969-76.

11. Keskin H, Kaya Y, Cadırcı K, Kucur C, Ziypak E, Simsek $\mathrm{E}$, et al. Elevated neutrophil/lymphocyte ratio in patients with euthyroid chronic autoimmune thyreotidis. Endocrine Regulation 2016; 50: 148-53. that there is a need for more extensive work in this regard.

\section{Conflict of interest statement}

The authors stated that they have no conflicts of interest regarding the publication of this article.
12. Kaya A, Kurt M, Tanboga HI, Işık T, Günaydın ZY, Kaya $Y$, et al. Relation of neutrophil to lymphocyte ratio with the presence and severity of stable coronary artery disease. Clin Appl Thromb Hemost 2014; 20: 473-77.

13. Ansell JE. The Blood in Thyrotoxicosis. In: Braverman LE, Utiger RD, editors., eds. Werner and Ingbar's The Thyroid: A Fundamental and Clinical Text. 7th ed Philadelphia: Lippincott-Raven. 1996; p: 637-44.

14. Valent P. Low blood counts: immune mediated, idiopathic, or myelodysplasia. Hematology Am Soc Hematol Educ Program 2012; p: 485-91.

15. Toth EL, Mant MJ, Shivji S, Ginsberg J. Propylthiouracilinduced agranulocytosis: an unusual presentation and a possible mechanism. Am J Med 1988; 85: 725-27.

16. Kyritsi EMA, Yiakoumis $X$, Pangalis GA, Pontikoglou C, Pyrovolaki K, Kalpadakis C, et al. High Frequency of Thyroid Disorders in Patients Presenting With Neutropenia to an Outpatient Hematology Clinic STROBECompliant Article. Medicine (Baltimore) 2015; 94: e886.

17. Irvine WJ, Wu FCW, Urbaniak SJ, Toolis F. Peripheral blood leucocytes in thyrotoxicosis (Graves' disease) as studied by conventional light microscopy. Clin Exp Immunol 1977; 27: 216-21.

18. Aggarwal N, Tee SA, Saqip W. Treatment of hyperthyroidism with anti-thyroid drugs corrects mild neutropenia in Graves' disease. Clin Endocrinol (Oxf) 2016; 85: 949_ 53.

19. Bistrom O. On the morphology of blood and bone marrow in thyrotoxicosis. Acta Chir Scand 1946; 94: 11-88.

20. Eakin DL, Peake RL, Weiss GB. Effect of therapy on the neutropenia of hyperthyroidism. South Med J 1983; 76: 335-40.

21. Ladwig P, Coles R, Fisher E, Spurrett B. Thyrotoxicosis in pregnancy presenting as pancytopenia. Aust N Z J Obstet Gynaecol 1995; 35: 457-60.

22. Ponassi A, Morra L, Caristo G, Parodi GB, Biassoni P, Sacchetti C. Disorders of granulopoiesis in patients with untreated Graves' disease. Acta Haematol 1983; 70: 19-23.

23. Shaw B, Mehta AB. Pancytopenia responding to treatment of hyperthyroidism: a clinical case and review of the literature. Clin Lab Haematol 2002; 24: 385-87. 
24. Grymuła K, Paczkowska E, Dziedziejko V, Baskiewicz MM, Kawa M, Baumert $B$, et al. The influence of 3,3 ,5triiodo-L-thyronine on human haematopoiesis. Cell Prolif 2007; 40: 302-15.

25. Weitzman SA, Stossel TP, Harmon DC, Daniels G, Maloof F, Ridgway EC. Antineutrophil antibodies in Graves' disease. Implications of thyrotropin binding to neutrophils. J Clin Invest 1985; 75: 119-23.s

26. Pedersen BK, Feldt-Rasmussen U, Bech $K$, Perrild $H$, Klarlund K, Høier-Madsen M. Characterization of the natural killer cell activity in Hashimoto's and Graves' diseases. Allergy 1989; 44: 477-81.
27. Corrales JJ, Orfao A, Miralles JM, San Miguel J. The relationship between hyperthyroidism and the distribution of peripheral blood T, NK and B-lymphocytes in multinodular goiter. Horm Metab Res 1994; 26: 104-08.

28. Kocer D, Karakukcu C, Karaman H, Gokay F, Bayram F. May the neutrophil/lymphocyte ratio be a predictor in the differentiation of different thyroid disorders? Asian Pac J Cancer Prev 2015; 16: 3875-79.

29. Yaylacı S, Tosun O, Sahin O, Genc AB, Aydin E, Demiral $G$, et al. Lack of Variation in Inflammatory Hematological Parameters between Benign Nodular Goiter and Papillary Thyroid Cancer. Asian Pac J Cancer Prev 2016; 17: 2321-23.

Received: December 12, 2018

Accepted: January 23, 2019 